\title{
New biofunctional effects of the flower buds of Camellia sinensis and its bioactive acylated oleanane-type triterpene oligoglycosides
}

\author{
Hisashi Matsuda ${ }^{1} \cdot$ Seikou Nakamura ${ }^{1} \cdot$ Toshio Morikawa $^{2} \cdot$ Osamu Muraoka $^{2}$. \\ Masayuki Yoshikawa ${ }^{1}$
}

Received: 31 March 2016/ Accepted: 13 June 2016/Published online: 5 July 2016

(C) The Japanese Society of Pharmacognosy and Springer Japan 2016

\begin{abstract}
We review the biofunctional effects of the flower buds of Camellia sinensis and $C$. sinensis var. assamica, such as antihyperlipidemic, antihyperglycemic, antiobesity, and gastroprotective effects in vivo, and antiallergic, pancreatic lipase inhibitory, and amyloid $\beta(\mathrm{A} \beta)$ aggregation inhibitory activities in vitro. Although the biofunctional effects of tea leaves have been extensively studied, less attention has been given to those of the flowers and seeds of the tea plant. Our studies focused on the saponin constituents of the extracts of the flower buds of $C$. sinensis cultivated in Japan and China, and $C$. sinensis var. assamica cultivated in India, and we review their beneficial biofunctions for health promotion.
\end{abstract}

Keywords Camellia sinensis - Camellia sinensis var. assamica - Flower buds - Chakasaponin .

Floratheasaponin · Floraassamsaponin - Biofunctional effect

\section{Introduction}

Tea made from the leaves of the plant Camellia sinensis has been used since ancient times for medicinal purposes, and is now consumed as a popular beverage. Cultivated in more than 30 countries, $>4$ million tons of tea are produced annually. Depending on the processing of the leaves, tea is

Hisashi Matsuda

matsuda@mb.kyoto-phu.ac.jp

1 Kyoto Pharmaceutical University, Misasagi, Yamashina-ku, Kyoto 607-8412, Japan

2 Pharmaceutical Research and Technology Institute, Kindai University, 3-4-1 Kowakae, Higashi-Osaka, Osaka 577-8502, Japan classified into two major types-green tea and black tea. While black tea is the major type of tea produced and consumed worldwide, green tea is more popular than black tea in China and Japan. Tea has been studied for its beneficial health effects, such as reduction of body weight, alleviation of metabolic syndrome, prevention of cardiovascular diseases and cancer, and protection against neurodegeneration. With regard to the mechanisms responsible for metabolic syndrome, decreased absorption of lipids by tea polyphenols such as (-)-epigallocatechin 3-O-gallate at the intestine, and activation of adenosine monophosphate (AMP)-activated protein kinase by tea polyphenols that are bioavailable in the liver, skeletal muscle, and adipose tissues have been demonstrated. Activation of AMP-activated protein kinase decreases gluconeogenesis and fatty acid synthesis and increases catabolism, leading to body weight reduction and alleviation of metabolic syndrome [1].

Although the biofunctional effects of tea leaves have been studied extensively, less attention has been given to those of the flowers and seeds of the tea plant. We have previously reported the various tea saponins, asssamsaponins, and camelliasaponins (classified as acylated oleanane-type triterpene oligogycosides) from the seeds of C. sinensis and C. sinensis var. assamica [2-9]. Among them, theasaponins $E_{1}, E_{2}, E_{5}$, and assamsaponin $C$ (at a low dose of $5.0 \mathrm{mg} / \mathrm{kg}$ ) showed protective effects on ethanol-induced gastric mucosal lesions in rats $[3,5,6]$, and theasaponin $\mathrm{E}_{1}$ inhibited gastric emptying, and elicited an accelerating effect on gastrointestinal transit [4]. Foliatheasaponins from the leaves of Japanese $C$. sinensis (Tencha) have also been reported to display such effects [10]. With regard to the biofunctions of the tea flower ('Chaka' in Japanese), we have reported the beneficial biofunctions of the extract for health promotion-antihyperlipidemic [11, 12], antihyperglycemic [12, 13], 
gastroprotective [13], and antiobesity effects [14] in vivo, with antiallergic [15], pancreatic lipase inhibitory [16], and amyroid $\beta(A \beta)$ aggregation inhibitory effects [17].

Here, we focused on the saponin constituents of the flower bud extracts of $C$. sinensis cultivated in Japan (Japanese Chaka), Anhui, Sichuan, and Fujian provinces of China (Anhui, Sichuan and Fujian Chaka), and C. sinensis var. assamica cultivated in India (Indian Assam Chaka) and on their biofunctional effects. We further divided the review into three parts-(A) Japanese and Anhui Chaka, (B) Fujian Chaka, and (C) Indian Assam Chaka, based on their saponin constituents and the variety of plant.

\section{The biofunctional effects of Japanese and Anhui Chaka}

With regard to the biofunctional effects of Japanese and Anhui Chaka, we documented the antihyperlipidemic, antihyperglycemic, and gastroprotective effects of the methanolic $(\mathrm{MeOH})$ extract in mice and rats, and provided findings on the antiallergic activity and inhibitory action of pancreatic lipase, rat intestinal $\alpha$-glucosidase, and rat lens aldose reductase (in vitro).

\section{Antihyperlipidemic and antihyperglycemic effects}

With regard to antihyperlipidemic properties, we observed the effect of the $\mathrm{MeOH}$ extract from Japanese and Anhui Chaka on increased plasma triglyceride (TG) levels in olive oil-loaded mice [11]. The $\mathrm{MeOH}$ extract (34.1\% from the material) $(500-1,000 \mathrm{mg} / \mathrm{kg}$, p.o.) and $n$-BuOH-soluble fraction $(15.8 \%)(500 \mathrm{mg} / \mathrm{kg}$, p.o.) of Japanese Chaka significantly inhibited increased plasma TG levels in olive oil-loaded mice [11].

With regard to the antihyperglycemic properties, we also observed the effect of the $\mathrm{MeOH}$ extract of Japanese Chaka on increased serum glucose levels in sucrose-loaded rats, rat intestinal $\alpha$-glucosidase and rat lens aldose reductase. Briefly, the $\mathrm{MeOH}$ extract $(1,000 \mathrm{mg} / \mathrm{kg}$, p.o) and $n-\mathrm{BuOH}$-soluble $(500 \mathrm{mg} / \mathrm{kg}$, p.o.) fraction significantly inhibited plasma glucose elevation in rats. In addition, the extract significantly inhibited rat lens aldose reductase $\left(\mathrm{IC}_{50} 72 \mu \mathrm{g} / \mathrm{mL}\right.$ ), although inhibition of rat intestinal $\alpha$-glucosidase by the extract was weak [13].

In the course of our studies on the saponin composition of tea plants, acylated oleanane-type triterpene oligoglycosides, floratheasaponins A (1)-J (10), were isolated from Japanese Chaka and Anhui Chaka, and their structures were elucidated on the basis of chemical and physicochemical evidence $[11,15,18]$ (Fig. 1). However, although we were not able to isolate floratheasaponins from Fujian Chaka, instead we obtained chakasaponins I (11)-IV (14) $[11,16]$.
These findings were supported by qualitative and quantitative analyses of floratheasaponins and chakasaponins in Chaka from different regional origins. Briefly, the floratheasaponin content in the Fujian and Sichuan Chaka is lower than those in Japan, Taiwan, and India [13, 19]. Furthermore, the floratheasaponin content in Japanese Chaka varies markedly during the blooming periods, and is abundant at half-bloom [13]. In addition, the caffeine content in the flower buds is lower than the tea leaves [13].

Floratheasaponins A (1)-C (3) from Japanese Chaka at 50 and $100 \mathrm{mg} / \mathrm{kg}$ p.o. significantly inhibited TG elevation in olive oil-loaded mice [11], and on serum glucose elevation in sucrose-loaded rats [13] (Table 1). Comparing the effects of 1-3 with those of theasaponins $E_{1}$ and $E_{2}$ from the seeds of $C$. sinensis suggests that the 21 and 22-acyl groups are essential, although the 23 -aldehyde group is not relevant to the antihyperlipidemic activity [11].

\section{Gastromucosal protection}

We further studied the protective effect of Japanese Chaka on ethanol and indomethacin-induced gastric lesions in rats. The $\mathrm{MeOH}$ extract $(5-50 \mathrm{mg} / \mathrm{kg})$ dose-dependently inhibited gastric lesions, and floratheasaponins A (1)-C (3) significantly inhibited ethanol-induced gastric lesions [13]. In fact, their effects were stronger than that of cetraxate hydrochloride (used as a positive control; Table 2).

\section{Antiallergic effects in vitro}

Histamine, which is released from mast cells stimulated by an antigen or a degranulation inducer, is usually determined as a degranulation marker in in vitro experiments on immediate allergic reactions. $\beta$-Hexosaminidase is also stored in secretory granules of mast cells and basophils, and is also released concomitantly with histamine when mast cells are immunologically activated. Therefore, it is generally accepted that $\beta$ hexosaminidase is a degranulation marker of mast cells, and this assay has been used for the evaluation of antiallergic compounds as an alternative to passive cutaneous anaphylaxis reactions in laboratory animals [20].

Park et al. reported that the dammarane-type triterpene glycoside, ginsenoside $\mathrm{Rh}_{2}$, exhibited inhibitory activity on $\beta$-hexosaminidase release from rat basophilic leukemia (RBL-2H3) cells, an activity suggested to originate from cell membrane-stabilizing action [21]. Acylated oleananetype triterpene oligoglycosides, floratheasaponins A (1)-F (6), were also expected to exhibit cell membrane-stabilizing action. Therefore, we examined the effects of these floratheasaponins (1-6) on the release of $\beta$-hexosaminidase induced by dinitrophenylated bovine serum albumin (DNPBSA) from RBL-2H3 cells sensitized with anti-DNP immunoglobulin E. 
Fig. 1 Chemical structures of acylated oleanane-type triterpene oligoglycosides from the flower buds of $C$. sinensis cultivated in Japan and China, and $C$. sinensis var. assamica cultivated in India

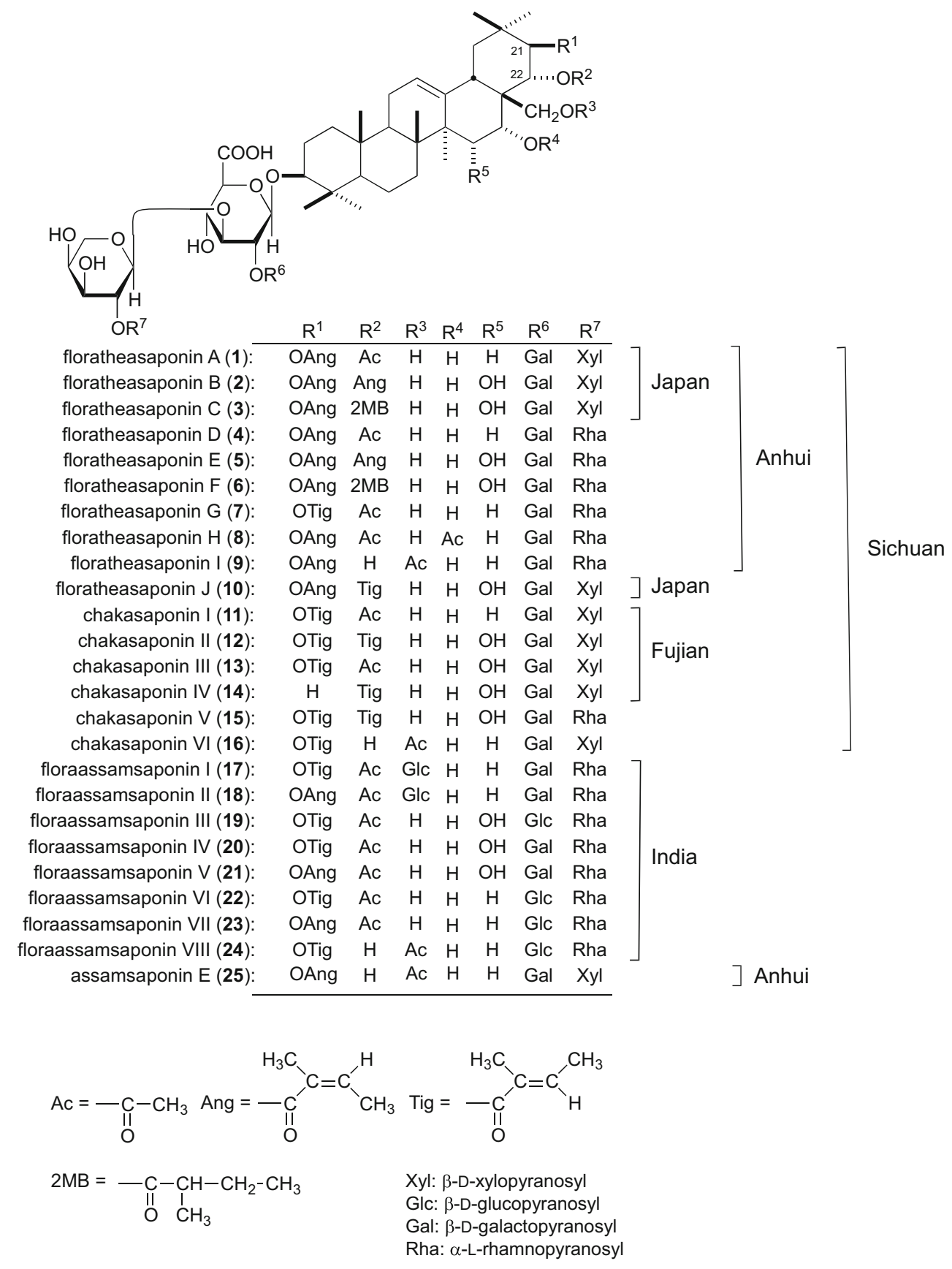

The $\mathrm{MeOH}$ extract (38.5\% from the material) from Anhui Chaka exhibited a significant inhibitory effect on the release of $\beta$-hexosaminidase from RBL-2H3 cells (inhibition $43.5 \pm 2.4 \%$ at $100 \mu \mathrm{g} / \mathrm{mL}, p<0.01)$. The ethyl acetate (EtOAc)- and $n$-BuOH-soluble fractions inhibited antigeninduced degranulation in RBL-2H3 cells at $100-30 \mu \mathrm{g} / \mathrm{mL}$ (inhibition $18.1 \pm 4.0 \%, p<0.05$ and $60.1 \pm 2.9 \%$, $p<0.01$, respectively), although the $\mathrm{H}_{2} \mathrm{O}$-soluble fraction did not show such an effect. Floratheasaponins (1-6) were found to show inhibitory effects on antigen-induced degranulation. In particular, floratheasaponins B (2) and E (5) exhibited significant inhibitory effects of $59.8 \pm 3.6 \%(p<0.01)$ and $52.3 \pm 3.2 \%(p<0.01)$ at $3 \mu \mathrm{M}$, respectively, and their activities were, in fact, more potent than those of two antiallergic compounds, tranilast and ketotifen fumarate [15].

\section{Biofunctional effects of Fujian Chaka}

We investigated the effects of the antihyperlipidemic, antihyperglycemic, and antiobesity properties of the $\mathrm{MeOH}$ extract $(31.1 \%$ from the material) from Fujian Chaka, 
Table 1 Effects of floratheasaponins A (1)-C (3) on serum triglyceride $(\mathrm{TG})$ elevation in olive oil-loaded mice and serum glucose elevation in sucrose-loaded rats. Data were taken and reproduced from references [11] and [13]

\begin{tabular}{|c|c|c|c|}
\hline Treatment & $\begin{array}{l}\text { Dose } \\
\text { (mg/kg, p.o.) }\end{array}$ & $\begin{array}{l}\text { Serum TG } \\
(\mathrm{mg} / 100 \mathrm{~mL}) \\
\text { at } 2.0 \mathrm{~h}\end{array}$ & $\begin{array}{l}\text { Serum glucose } \\
(\mathrm{mg} / 100 \mathrm{~mL}) \\
\text { at } 0.5 \mathrm{~h}\end{array}$ \\
\hline Normal & - & $140.8 \pm 5.9 * *$ & $80.3 \pm 2.7 * *$ \\
\hline Control & - & $566.6 \pm 22.2$ & $147.6 \pm 3.0$ \\
\hline \multirow[t]{3}{*}{ Floratheasaponin A (1) } & 25 & $411.0 \pm 34.3$ & - \\
\hline & 50 & $387.4 \pm 74.7^{*}$ & $122.5 \pm 8.8$ \\
\hline & 100 & $158.3 \pm 31.9^{* *}$ & $107.3 \pm 3.6^{* *}$ \\
\hline \multirow[t]{3}{*}{ Floratheasaponin B (2) } & 25 & $411.7 \pm 50.6$ & - \\
\hline & 50 & $316.9 \pm 63.0^{* *}$ & $120.3 \pm 10.5$ \\
\hline & 100 & $161.9 \pm 11.9^{* *}$ & $98.4 \pm 7.2^{* *}$ \\
\hline \multirow[t]{3}{*}{ Floratheasaponin C (3) } & 25 & $348.5 \pm 83.7 * *$ & - \\
\hline & 50 & $204.1 \pm 40.3^{* *}$ & $119.8 \pm 7.9^{* *}$ \\
\hline & 100 & $143.1 \pm 11.3 * *$ & $87.7 \pm 5.5^{* *}$ \\
\hline Normal & - & $154.3 \pm 9.3^{* *}$ & - \\
\hline Control & - & $387.1 \pm 39.2$ & - \\
\hline \multirow[t]{3}{*}{ Orlistat } & 6.25 & $266.4 \pm 31.1 *$ & - \\
\hline & 12.5 & $187.9 \pm 25.5^{* *}$ & - \\
\hline & 25 & $158.9 \pm 28.7 * *$ & - \\
\hline Normal & - & - & $85.6 \pm 3.6^{* *}$ \\
\hline Control & - & - & $159.6 \pm 7.0$ \\
\hline \multirow[t]{2}{*}{ Metoformin hydrochloride } & 50 & - & $134.8 \pm 4.3^{*}$ \\
\hline & 100 & - & $124.1 \pm 5.5^{* *}$ \\
\hline
\end{tabular}

Effects on serum TG levels in mice: each test sample was given orally to fasted ddY male mice, and olive oil $(5 \mathrm{~mL} / \mathrm{kg}$, p.o.) was given $30 \mathrm{~min}$ later. Blood samples were collected at 2, 4, and $6 \mathrm{~h}$ after olive oil treatment. Serum TG levels were determined by an enzymatic method using a commercially available kit Effects on serum glucose levels in rats: each test sample was given orally to fasted male Wistar rats, and a $20 \%$ (w/v) sucrose solution $(5 \mathrm{~mL} / \mathrm{kg}$, p.o.) was given 30 min later. Blood samples were collected at $0.5,1$, and $2 \mathrm{~h}$ after sucrose loading. Serum glucose levels were determined by an enzymatic method using a commercially available kit

Values represent the mean $\pm \operatorname{SEM}(n=5-15)$

Significant difference where $* p<0.05$ or $* * p<0.01$ was compared with controls along with their ability to inhibit gastric emptying, and accelerate gastrointestinal transit.

\section{Antihyperlipidemic and antihyperglycemic effects}

The $\mathrm{MeOH}$ extract (500 mg/kg, p.o.) of Fuijian Chaka also inhibited plasma TG elevation in olive oil-loaded mice and plasma glucose elevation in sucrose-loaded mice [12]. Chakasaponins I (11)-IV (14) isolated from Fujian Chaka, and their chemical structures were determined $[12,16]$. In addition, chakasaponins V (15) and VI (16) together with floratheasaponins A (1)-I (9), chakasaponins I (11)-III (13), and assamsaponin E (25) were isolated from the dried flower buds of $C$. sinensis cultivated in Sichuan province of China (Sichuan Chaka) [22]. Chakasaponins I (11)-III (13) from the $n$-BuOH-soluble fraction of Fujian Chaka at $50 \mathrm{mg} / \mathrm{kg}$ significantly inhibited plasma TG and glucose elevation in mice [12] (Table 3), without affecting the enzyme activity of rat intestinal $\alpha$-glucosidase. The $\mathrm{MeOH}$ extract and EtOAc- and $n$-BuOH-soluble fractions significantly inhibited pancreatic lipase, and the $\mathrm{IC}_{50}$ values of 11-13 were $0.17,0.18$ and $0.53 \mathrm{mM}$, respectively, without the desacyl derivative of $\mathbf{1 2}$ affecting it, suggesting that the 21 and 22-acyl groups are essential for the activity [16].

\section{Antiobesity effects in high-fat diet-fed mice and Tsumura Suzuki Obese Diabetes (TSOD) mice}

The effects of the $\mathrm{MeOH}$ extract on body weight gain in high-fat diet-fed mice and an experimental animal model of metabolic syndrome, TSOD mice, have been reported [14]. The $\mathrm{MeOH}$ extract $(500 \mathrm{mg} / \mathrm{kg} /$ day, p.o.) markedly inhibited body weight gain 9-14 days after administration in high-fat diet-fed mice (Fig. 2a). The $\mathrm{MeOH}$ extract (250 and/or $500 \mathrm{mg} / \mathrm{kg} /$ day, p.o.) significantly suppressed liver weight, liver TG and the weight of visceral fat. A positive control, bezafibrate (50 and $100 \mathrm{mg} / \mathrm{kg} /$ day, p.o.), significantly reduced body weight gain $(43.4 \pm 0.9 \mathrm{~g}$ at $50 \mathrm{mg} /$ 
Table 2 Inhibitory effects of floratheasaponins A (1)-C (3) on gastric lesions induced by ethanol in rats. Data were taken and reproduced from reference [13]

\begin{tabular}{llcc}
\hline Treatment & $\begin{array}{l}\text { Dose } \\
(\mathrm{mg} / \mathrm{kg}, \mathrm{p} . \mathrm{o} .)\end{array}$ & \multicolumn{2}{l}{ Gastric lesions } \\
\cline { 3 - 4 } & & Length $(\mathrm{mm})$ & Inhibition (\%) \\
\hline Control & - & $157.0 \pm 15.5$ & - \\
Floratheasaponin A (1) & 5 & $80.2 \pm 14.7$ & 48.9 \\
& 10 & $72.9 \pm 11.1^{* *}$ & 57.7 \\
& 20 & $24.2 \pm 10.2^{* *}$ & 88.4 \\
Floratheasaponin B (2) & 50 & $0.0 \pm 0.0^{* *}$ & 100.0 \\
& 5 & $92.8 \pm 24.2$ & 40.9 \\
& 10 & $55.4 \pm 12.2^{* *}$ & 64.7 \\
Control & 20 & $24.9 \pm 10.5^{* *}$ & 84.1 \\
Floratheasaponin C (3) & 50 & $11.5 \pm 7.7^{* *}$ & 92.7 \\
& - & $163.3 \pm 10.3$ & - \\
& 5 & $38.0 \pm 7.1^{* *}$ & 76.7 \\
& 10 & $22.3 \pm 6.8^{* *}$ & 86.3 \\
Control & 20 & $18.5 \pm 7.2^{* *}$ & 88.7 \\
Cetraxate hydrochloride & 50 & $0.0 \pm 0.0$ & 100.0 \\
& - & $148.4 \pm 9.8$ & - \\
& 75 & $87.2 \pm 7.4^{* *}$ & 41.2 \\
& 150 & $51.0 \pm 4.0^{* *}$ & 65.6 \\
\hline & 300 & $30.5 \pm 8.3^{* *}$ & 79.4 \\
\hline
\end{tabular}

Ethanol (99.5\%, $1.5 \mathrm{~mL} /$ rat, p.o.) was given to fasted male Sprague-Dawley rats $1 \mathrm{~h}$ before removal of the stomach, which was previously inflated by an injection of $10 \mathrm{ml}$ of $1.5 \%$ formalin to fix the inner and outer layers of the gastric walls. Subsequently, the stomach was incised along the greater curvature and the lengths of gastric lesions were measured, and the total length $(\mathrm{mm})$ was expressed as a lesion index. The test sample was administered $1 \mathrm{~h}$ before the ethanol treatment

Values represent the mean $\pm \operatorname{SEM}(n=6-12)$

Significant difference where $* * p<0.01$ was compared with controls $\mathrm{kg}, p<0.05$ and $43.0 \pm 1.1 \mathrm{~g}$ at $100 \mathrm{mg} / \mathrm{kg}, p<0.05 \mathrm{vs}$ $46.2 \pm 0.5 \mathrm{~g}$, control group) on day 14 after fasting. The compound also reduced the weight of visceral fat and plasma TG at $100 \mathrm{mg} / \mathrm{kg}$. Peroxisome proliferator-activated receptor (PPAR) $\alpha$ agonists including bezafibrate are reported to increase liver weight at higher doses in rats [23]. Consistent with this report, an increase in liver weight was observed in bezafibrate-treated mice. However, the $\mathrm{MeOH}$ extract did not show such an effect, and this result together with the lack of effect on plasma TG levels suggested that the extract might not act as a PPAR $\alpha$ agonist.

The extract $(500 \mathrm{mg} / \mathrm{kg} /$ day, p.o.) also significantly suppressed body weight gain of TSOD mice after one week (Fig. 2b). Three weeks later, a glucose tolerance test was performed using an intraperitoneal injection of glucose. The $\mathrm{MeOH}$ extract (250-500 mg/kg/day, p.o.) significantly suppressed an increase in plasma glucose levels $2 \mathrm{~h}$ after glucose loading. After 4 weeks, liver weight, weight of visceral fat, and plasma total cholesterol levels were significantly suppressed by the extract $(500 \mathrm{mg} / \mathrm{kg} / \mathrm{day}$, p.o.).

We speculated that the strong reduction of body weight within a week after extract treatment was mainly due to reduction of food intake. Therefore, the effect of the extract on food intake was examined in high-fat dietfed mice and TSOD mice. As shown in Fig. 3a and b, the extract inhibited food intake in a dose-dependent manner. Furthermore, this effect was also observed in normal diet-fed mice; the total intake for 5 days in the $\mathrm{MeOH}$ extract-treated group $(500 \mathrm{mg} / \mathrm{kg} /$ day, p.o.) was $19.3 \mathrm{~g}(p<0.01)$ vs $21.0 \mathrm{~g}$ in the control group, although an obvious toxic effect was not observed (except for body weight gain) [14].

Next, we examined the $n$-BuOH-, ethyl acetate (EtOAc)- and $\mathrm{H}_{2} \mathrm{O}$-soluble fractions from the $\mathrm{MeOH}$ extract. The $n$-BuOH-soluble fraction $(16.4 \%$ from the material) inhibited food intake at a dose of $250 \mathrm{mg} / \mathrm{kg} / \mathrm{day}$, p.o. (Fig. 4a), but the EtOAc- and $\mathrm{H}_{2} \mathrm{O}$-soluble fractions (3.2 and $11.5 \%$ from the material) had no such effect, when the fraction was given orally according to its yield.

With regard to the effect of the $n$-BuOH-soluble fraction on appetite signals, the effects on neuropeptide Y (NPY) and agouti-related protein (AgRP) mRNA levels in the hypothalamus were examined. NPY is an important regulator of body weight through its effects on food intake and energy expenditure. The majority of neurons expressing NPY in the hypothalamus are found within the arcuate 
Table 3 Effects of chakasaponins I (11) - III (13) and escin IIa on plasma triglyceride (TG) and glucose elevations in olive oil and sucrose-loaded mice. Data were taken and reproduced from reference [12]

\begin{tabular}{|c|c|c|c|}
\hline Treatment & $\begin{array}{l}\text { Dose } \\
\text { (mg/kg, p.o.) }\end{array}$ & $\begin{array}{l}\text { Plasma TG } \\
(\mathrm{mg} / 100 \mathrm{~mL}) \\
\text { at } 2.0 \mathrm{~h}\end{array}$ & $\begin{array}{l}\text { Plasma glucose } \\
(\mathrm{mg} / 100 \mathrm{~mL}) \\
\text { at } 0.5 \mathrm{~h}\end{array}$ \\
\hline Normal & - & $115.5 \pm 12.4^{* *}$ & $128.5 \pm 5.3 * *$ \\
\hline Control & - & $440.5 \pm 45.2$ & $226.9 \pm 8.2$ \\
\hline \multirow[t]{3}{*}{ Chakasaponin I (11) } & 25 & $435.7 \pm 67.4$ & - \\
\hline & 50 & $284.2 \pm 9.6^{* *}$ & $199.6 \pm 8.7 * *$ \\
\hline & 100 & - & $196.8 \pm 8.2 * *$ \\
\hline Normal & - & $152.4 \pm 13.5^{* *}$ & $116.5 \pm 7.9 * *$ \\
\hline Control & - & $553.8 \pm 49.8$ & $221.5 \pm 14.4$ \\
\hline \multirow[t]{3}{*}{ Chakasaponin II (12) } & 25 & $431.8 \pm 49.8 * *$ & - \\
\hline & 50 & $249.5 \pm 31.1 * *$ & $185.7 \pm 9.9 * *$ \\
\hline & 100 & - & $178.5 \pm 8.3^{* *}$ \\
\hline Normal & - & $124.0 \pm 8.4^{* *}$ & $126.5 \pm 4.0^{* *}$ \\
\hline Control & - & $407.2 \pm 73.0$ & $238.7 \pm 5.9$ \\
\hline \multirow[t]{3}{*}{ Chakasaponin III (13) } & 25 & $394.1 \pm 81.4$ & - \\
\hline & 50 & $214.4 \pm 62.7 *$ & $215.9 \pm 10.6^{* *}$ \\
\hline & 100 & - & $189.0 \pm 10.2 * *$ \\
\hline Normal & - & $91.9 \pm 9.4 * *$ & - \\
\hline Control & - & $440.3 \pm 60.2$ & - \\
\hline \multirow[t]{2}{*}{ Orlistat } & 5 & $371.3 \pm 41.5$ & - \\
\hline & 10 & $203.8 \pm 52.1^{* *}$ & - \\
\hline Normal & - & - & $124.8 \pm 7.3 * *$ \\
\hline Control & - & - & $218.7 \pm 4.0$ \\
\hline \multirow[t]{2}{*}{ Acarbose } & 10 & - & $162.4 \pm 11.7 * *$ \\
\hline & 20 & - & $153.8 \pm 10.2 * *$ \\
\hline Normal & - & $114.9 \pm 18.1^{* *}$ & $122.2 \pm 6.3 * *$ \\
\hline Control & - & $546.7 \pm 59.4$ & $263.3 \pm 16.2$ \\
\hline \multirow[t]{2}{*}{ Escin IIa } & 50 & $464.2 \pm 45.3$ & $254.2 \pm 14.0$ \\
\hline & 100 & $308.9 \pm 61.4 *$ & $206.4 \pm 12.9 * *$ \\
\hline
\end{tabular}

Effects on plasma TG levels in mice: each test sample was given orally to fasted male ddY mice and olive oil $(5 \mathrm{~mL} / \mathrm{kg}$, p.o.) was given $30 \mathrm{~min}$ later. Blood samples were collected at 2,4 , and $6 \mathrm{~h}$ after olive oil treatment. Plasma TG levels were determined by an enzymatic method using a commercially available kit

Effects on plasma glucose levels in mice: each test sample was given orally to fasted male ddY mice, and a 10 (w/v) \% sucrose solution ( $10 \mathrm{~mL} / \mathrm{kg}$, p.o.) was given $30 \mathrm{~min}$ later. Blood samples were collected at 0.5 , 1 , and $2 \mathrm{~h}$ after sucrose loading. Plasma glucose levels were determined by an enzymatic method using a commercially available kit

Values represent the mean $\pm \operatorname{SEM}(n=5-9)$

Significant difference where $* p<0.05$ or $* * p<0.01$ was compared with controls nucleus (ARC) and most co-express AgRP. The ablation of NPY/AgRP neurons in young mice reduces food intake and body weight, and an intracerebroventricular injection of NPY potently stimulates food intake in adult rats [24]. In our study, the $n$-BuOH-soluble fraction administrated at $250 \mathrm{mg} / \mathrm{kg}$ for 4 days significantly suppressed the expression of NPY mRNA (Fig. 5). These findings suggest that the $n$-BuOH-soluble fraction inhibited food intake by suppressing appetite signals.

Furthermore, a principal saponin, chakasaponin II (12), induced a similar suppression of food intake $(50 \mathrm{mg} /$ kg/day, p.o.) (Fig 4b). In addition, 12 (50 mg/kg/day, p.o.) significantly inhibited NPY mRNA levels in the hypothalamus similar to the $n$-BuOH-soluble fraction (Fig. 5). These results suggest that the saponins are active constituents of the extract. Furthermore, the desacyl derivative of 12, desacyl-floratheasaponin $\mathrm{B}$, failed to produce the effect (Fig. 4c), suggesting that the 21 and 22-acyl groups are important for the activity.

Recently, an anti-cancer drug, cisplatin, and selective serotonin reuptake inhibitors (SSRIs) have been reported to inhibit food intake, and the involvement of 5-hydroxytryptamine $2\left(5-\mathrm{HT}_{2}\right)$ receptors in appetite control has been shown. Appetite is suppressed when the $5-\mathrm{HT}_{2 \mathrm{~B}}$ receptor in 
Fig. 2 Effects of the $\mathrm{MeOH}$ extract of Fujian Chaka on body weight gain in high-fat diet-fed mice and Tsumura Suzuki Obese Diabetes (TSOD) mice. a Male ddY mice were fed a high-fat diet (45 kcal \% fat, D12451; Research Diet, Inc.) or normal diet (10 kcal \% fat, D12450B; Research Diet, Inc.) for 14 days. The test sample was given orally once a day. b TSOD and Tsumura Suzuki Non-obesity (TSNO) mice were fed a standard laboratory chow MF (Oriental Yeast Co., Ltd.) for 28 days. The test sample was given orally once a day. Each value represents the mean with SEM $(n=6-10)$.

Significant difference where ${ }^{*} p<0.05$ or $* * p<0.01$ was compared with controls. Data were taken from reference [14]

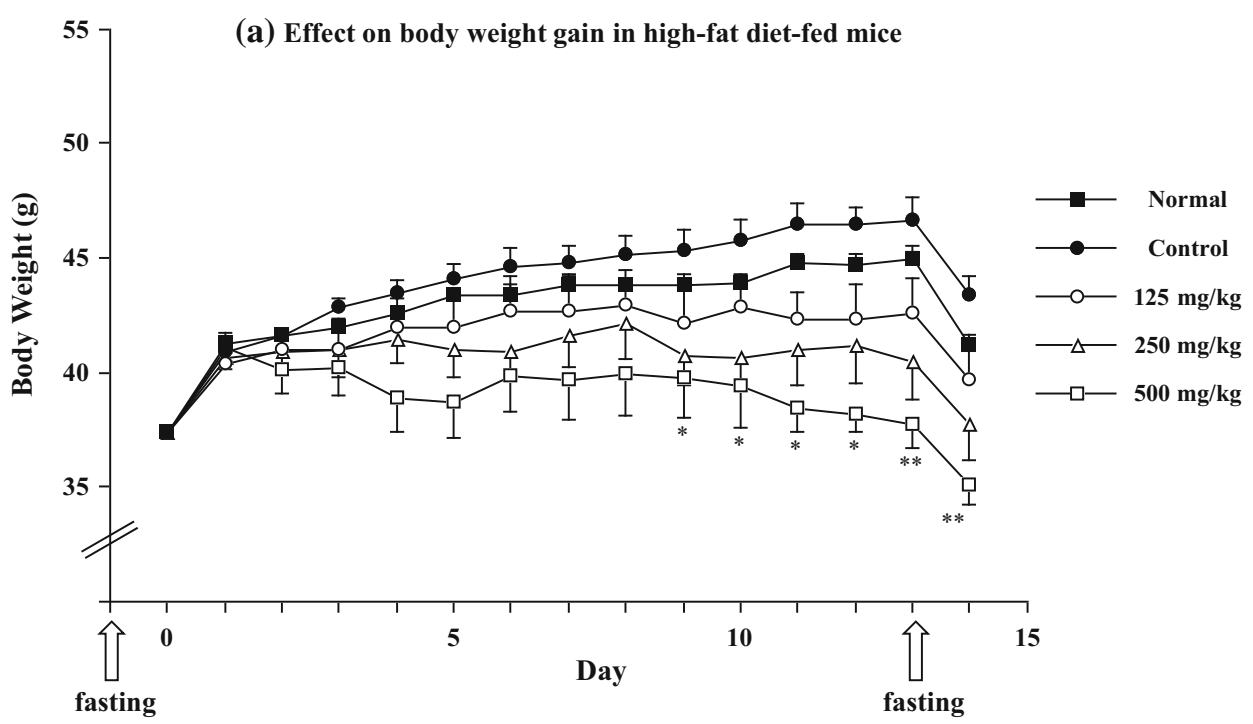

(b) Effect on body weight gain in TSOD mice

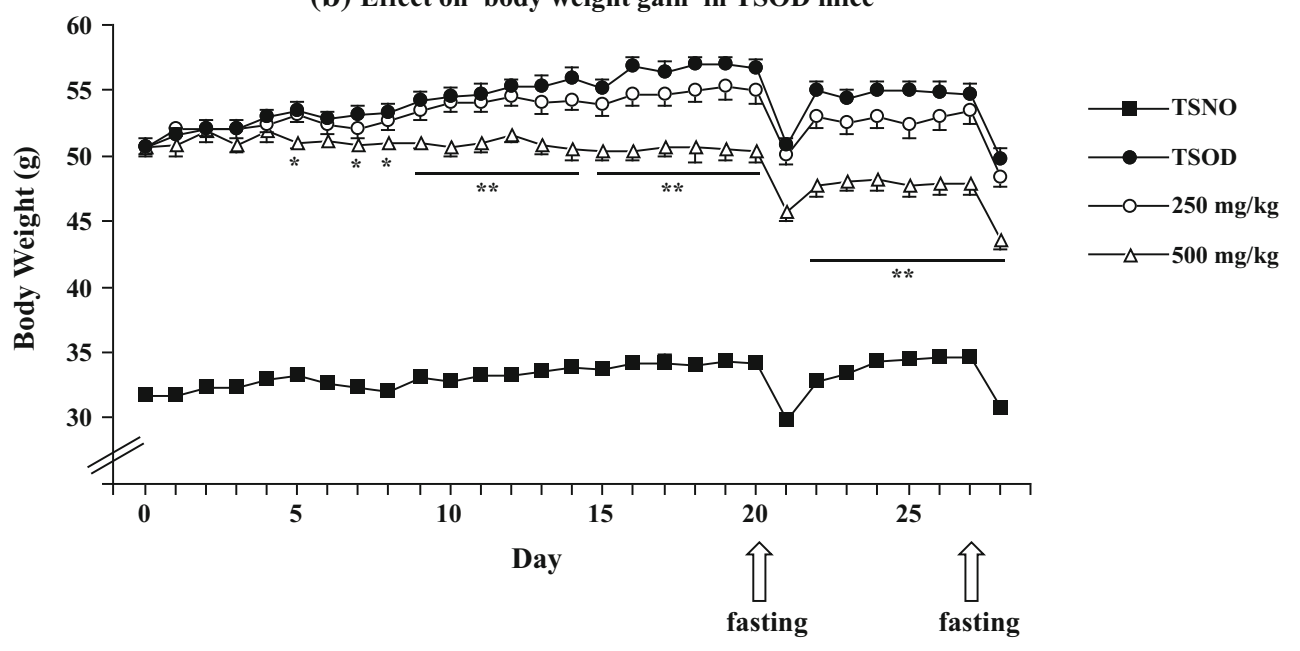

gastric smooth muscle and the $5-\mathrm{HT}_{2 \mathrm{C}}$ receptor in the hypothalamus are activated. 5-HT produced during treatment with cisplatin or SSRIs binds to various receptor subtypes and is likely to stimulate $5-\mathrm{HT}_{2 \mathrm{~B}}$ and $5-\mathrm{HT}_{2 \mathrm{C}}$ receptors. Stimulation of $5-\mathrm{HT}_{2 \mathrm{~B}}$ receptor decreases plasma ghrelin levels, and suppresses appetite signals via afferent vagal nerves [25-27]. Consistent with previous reports, 5-HT (serotonin creatinine sulfate monohydrate, $1 \mathrm{mg} / \mathrm{kg}$, i.p.) inhibited food intake in mice (Fig. 4d). In our study, we investigated the release of 5-HT from isolated ilea of mice and its retention in the tissues. Chakasaponin II (12) at $1.0 \mathrm{mM}$ significantly enhanced the release of 5-HT into the medium and reduced its retention in the tissues [14]. This concentration is relatively high, but concentrations of saponin in the intestinal tract are thought to be generally high, since this type of compound is difficult to be absorbed [28]. Furthermore, the effects of $n$-BuOH-soluble fraction and chakasaponin II (12) on food intake were obviously reduced in the capsaicin-pretreated mice in which the capsaicin-sensitive sensory nerves were densensitized by pretreatment with a high dose of capsaicin (Fig. 4a, b). In our pre-examination, chakasaponin II (12) increased plasma cholecystokinin (CCK) and glucagon-like peptide-1 (GLP-1) levels in mice (Table 4). CCK and GLP-1 are known to influence satiety signals secreted from intestinal I-cells and L-cells [29]. These findings suggest that their inhibitory effects on food intake were initiated by excretion of CCK and GLP-1, and were mediated via capsaicin-sensitive sensory nerves, probably the afferent vagal nerves (Fig. 6).

\section{Effects on gastric emptying in mice}

Previously, several saponins with similar structures, escins from the seeds of $A$. turbinata, were documented to show antihyperlipidemic effects in lipid emulsion-loaded mice, 
Fig. 3 Effects of the $\mathrm{MeOH}$ extract of Fujian Chaka on food intake in high-fat diet-fed mice and TSOD mice. a Male ddY mice were fed a high-fat diet (45 kcal \% fat) or normal diet (10 kcal \% fat) for 14 days. The test sample was given orally once a day. b TSOD and TSNO mice were fed a standard laboratory chow MF (Oriental Yeast Co., Ltd.) for 28 days. The test sample was given orally once a day. Each value represents the mean for 6-10 mice. Significant difference where $* p<0.05$ or $* * p<0.01$ was compared with controls. Refer to Fig. 2 for other abbreviations. Data were taken from reference [14]

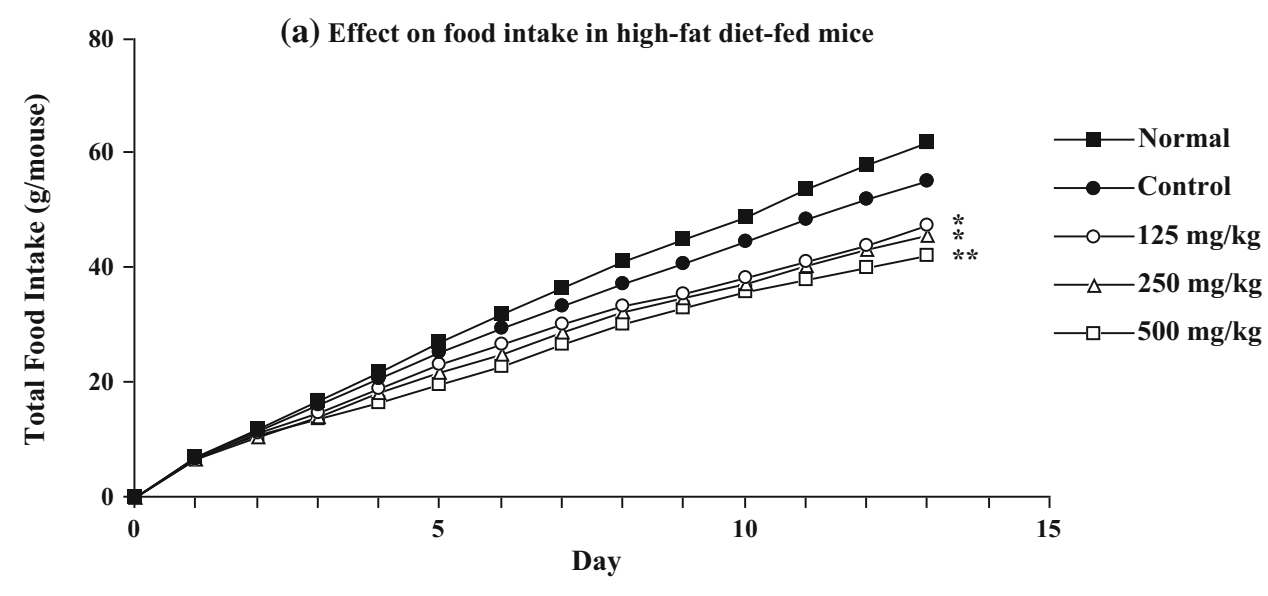

(b) Effect on food intake in TSOD mice

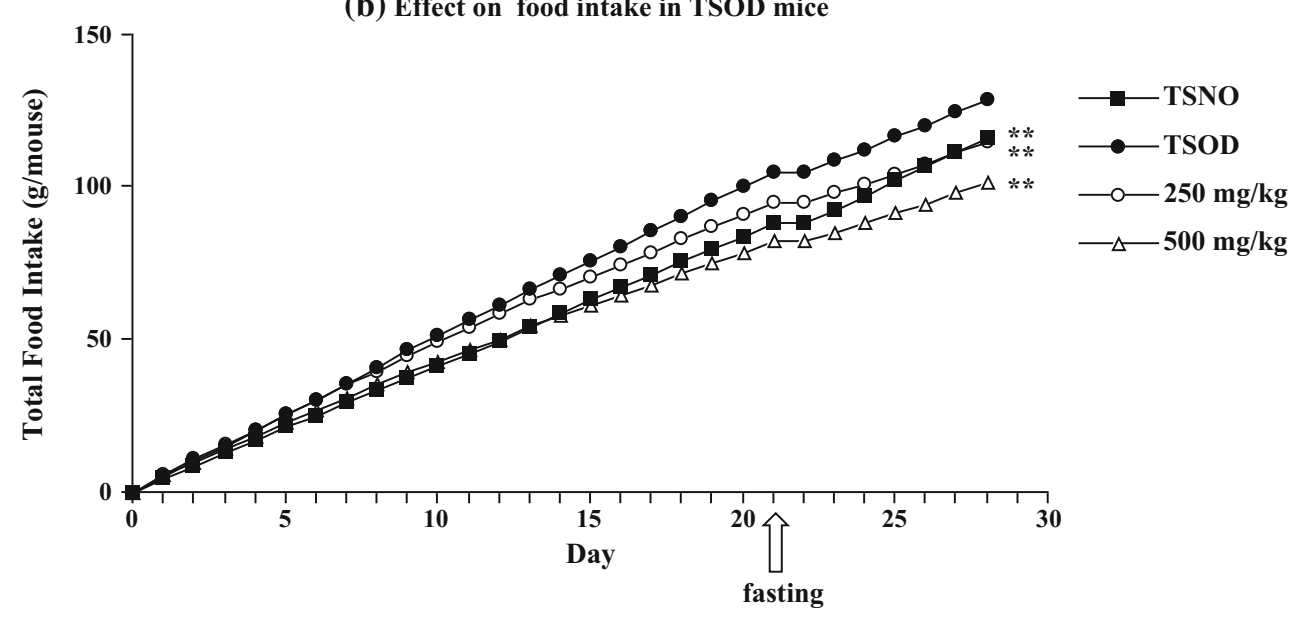

and inhibition of pancreatic lipase activity is suggested to be partly involved in this effect [30]. However, we considered that their antihyperlipidemic effects are mainly dependent on the inhibition of gastric emptying [31]. We, therefore, examined the effects of the $\mathrm{MeOH}$ extract and its $n$-BuOH-soluble fraction on gastric emptying in mice. The amount of phenol red in the stomach was determined 30 min after oral administration of carboxymethyl cellulose sodium salt (CMC-Na) containing phenol red.

The $\mathrm{MeOH}$ extract $(125-500 \mathrm{mg} / \mathrm{kg}$, p.o.) and $n-\mathrm{BuOH}-$ soluble fraction $(125-250 \mathrm{mg} / \mathrm{kg}$, p.o.) significantly inhibited gastric emptying in a dose-dependent manner. Furthermore, chakasaponins I (11) and II (12) $(25-50 \mathrm{mg} / \mathrm{kg})$ also inhibited gastric emptying in mice [12, 14] (Table 5).

In a previous report, we observed that the inhibitory effects of escins on gastric emptying involved the release of dopamine and dopamine 2 receptors via mechanisms involving capsaicin-sensitive sensory nerves, probably certain vagal afferent nerves [32]. Tominaga et al. reported that 5-HT inhibited gastric emptying in rats [33]. Consistent with the previous report, 5-HT (serotonin creatinine sulfate monohydrate, $10 \mathrm{mg} / \mathrm{kg}$, i.p.) significantly inhibited gastric emptying under our experimental conditions, although the effective dose of 5-HT was higher than for food intake [14].

As described above, the inhibitory effects of escins on gastric emptying involved the capsaicin-sensitive sensory nerves, probably certain vagal afferent nerves [31]. Pretreatment with capsaicin partly reduced the inhibitory effects of the $n-\mathrm{BuOH}$-soluble fraction and chakasaponins I (11) and II (12) on gastric emptying, suggesting that certain afferent vagal nerves are involved, at least in part, in the inhibition of gastric emptying as well as food intake. Bugajski et al. observed that long-term vagal electrical stimulation reduces food intake and body weight in rats [34]. Therefore, in addition to release of 5-HT, CCK, and GLP-1, other mechanisms of action including the direct stimulation of the vagal nerves by saponins warrant further study.

\section{Acceleration of gastrointestinal transit}

Gastrointestinal transit accelerating effects are thought to be beneficial for the prevention and treatment of the inhibition of gastrointestinal transit, such as the effects on the 
(a) $n$-BuOH-soluble fraction

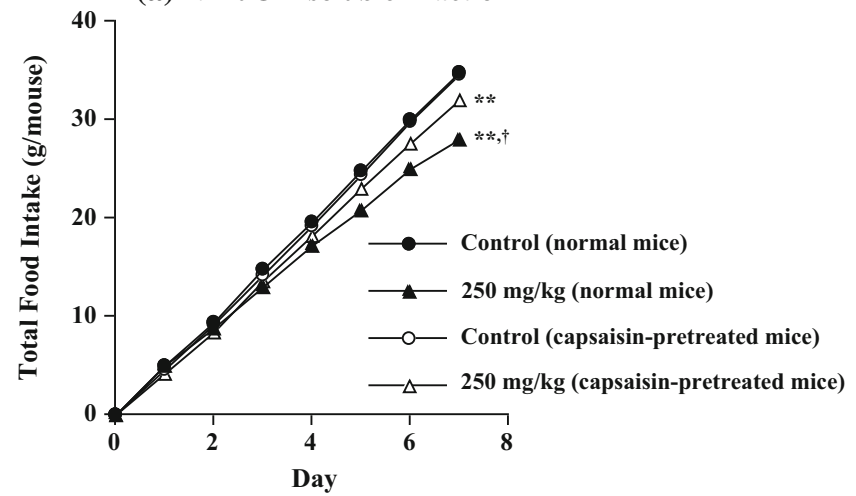

(c) Desacyl-floratheasaponin B

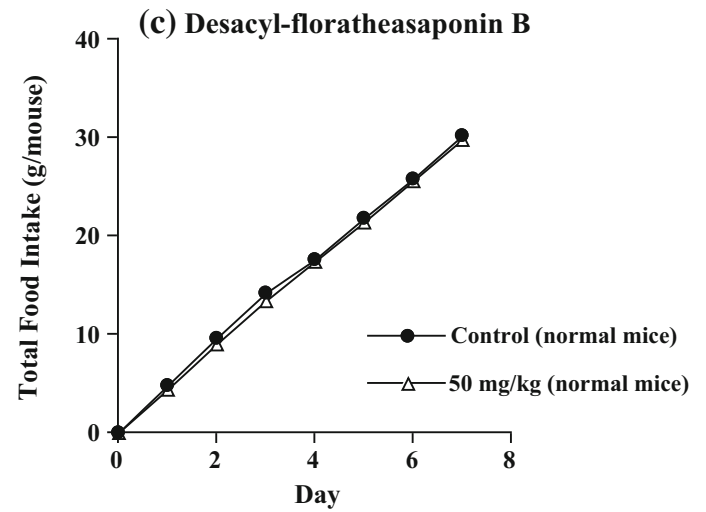

Fig. 4 Effects of the BuOH-soluble fraction of Fujian Chaka, chakasaponin II (12), desacyl-floratheasaponin B, and 5-HT on food intake in normal mice and/or capsaicin-pretreated mice. Male ddY mice were fed a standard laboratory chow MF (Oriental Yeast Co., Ltd.) for 8 days. The test sample was given orally once a day.

\section{NPY mRNA}

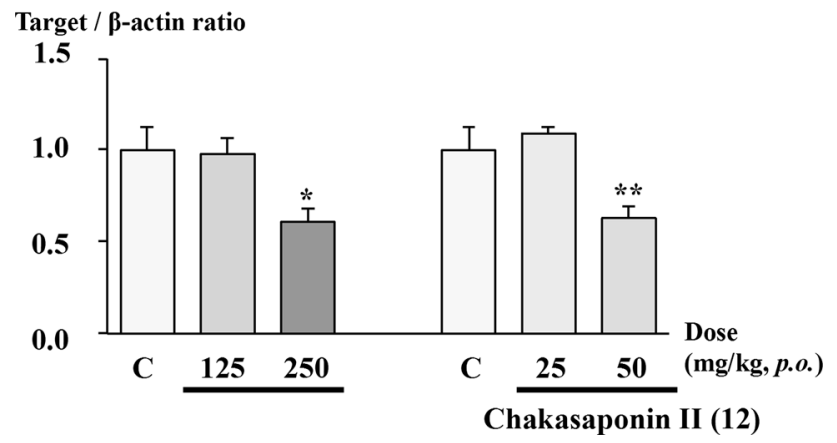

Fig. 5 Effects of $n$-BuOH-soluble fraction and chakasaponin II (12) on neuropeptide Y (NPY) mRNA levels in mice. The test sample was given orally to male ddY mice once a day. Four days later, the hypothalamus was dissected out, and the NPY mRNA levels were determined using real-time polymerase chain reaction. Each bar represents the mean $\pm \operatorname{SEM}(n=6)$. Significant difference where $* p<0.05$ or $* * p<0.01$ was compared with controls. Data were taken and reproduced from reference [14]
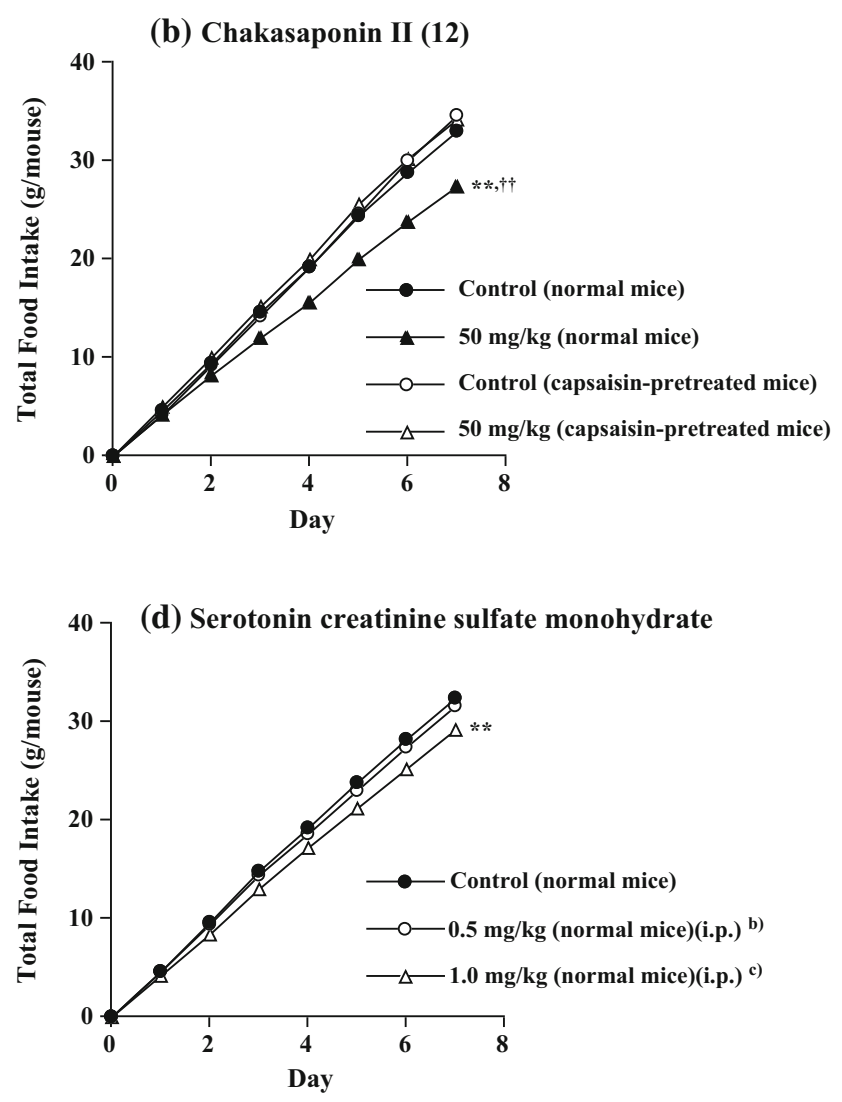

b, c These doses are equivalent to approximately $0.2-0.4 \mathrm{mg} / \mathrm{kg}$ serotonin. Each value represents the mean of 5 or 6 mice. Significant differences where ${ }^{* *} p<0.01$ and ${ }^{\dagger} p<0.05$ or ${ }^{\dagger} p<0.01$ were compared with controls and capsaicin-treated group, respectively. Data were taken from reference [14]

ileus in clinical situations. We have previously reported that escins and theasaponin $\mathrm{E}_{1}$ showed similar effects as those of the seeds of A. hippocastanum and C. sinensis var. assamica [4, 35] which also have similar structures. The $\mathrm{MeOH}$ extract $(500 \mathrm{mg} / \mathrm{kg}$, p.o.) and $n$-BuOH-soluble fraction $(200 \mathrm{mg} / \mathrm{kg}$, p.o.) from Fujian Chaka displayed an accelerating effect on gastrointestinal transit in mice. In a similar fashion, chakasaponins I (11)-III (13) (50 or $100 \mathrm{mg} / \mathrm{kg}$, p.o.) also demonstrated such accelerating effects [16] (Table 5).

\section{Saponin constituents and biofunctional effects of Indian Assam Chaka}

Eight acylated oleanane-type triterpene oligoglycosides, floraassamsaponins I (17)-VIII (24), together with floratheasaponins D (4), G (7) and I (9), were isolated from 
Table 4 Effects of chakasaponin II (12) on plasma GLP-1 and CCK levels in mice

\begin{tabular}{lllll}
\hline Treatments & $\begin{array}{l}\text { Dose } \\
(\mathrm{mg} / \mathrm{kg}, \mathrm{p} . \mathrm{o} .)\end{array}$ & $\begin{array}{l}\text { Food intake } \\
(\mathrm{g} / 30 \mathrm{~min})\end{array}$ & $\begin{array}{l}\text { Plasma GLP-1 } \\
(\mathrm{pg} / \mathrm{mL})\end{array}$ & $\begin{array}{l}\text { Plasma CCK } \\
(\mathrm{pg} / \mathrm{mL})\end{array}$ \\
\hline Control & - & $1.31 \pm 0.06$ & $20.0 \pm 3.4$ & $419 \pm 25$ \\
Chakasaponin II (12) & 25 & $1.19 \pm 0.08$ & $25.3 \pm 4.6$ & $681 \pm 70^{* *}$ \\
& 50 & $1.02 \pm 0.06^{* *}$ & $37.3 \pm 9.9^{*}$ & $702 \pm 112^{* *}$
\end{tabular}

Male ddY mice (6 weeks old) were fed a high-fat diet (45 kcal \% fat, D12451; Research Diets Inc.) for 7 days before the experiments. Test samples were given orally to the fasted mice 45 min before the midlight satiety test. The high-fat diet was then given to the mice for $30 \mathrm{~min}$, and the food intake within the 30-min period was measured for each group. A blood sample was collected from the portal vein under anesthesia, and plasma GLP-1 and CCK levels were measured by ELISA kits. Refer to Fig. 6 for abbreviations

Values represent the mean $\pm \operatorname{SEM}(n=7$ or 8$)$

Significant difference where $* p<0.05$ or $* * p<0.01$ was compared with controls

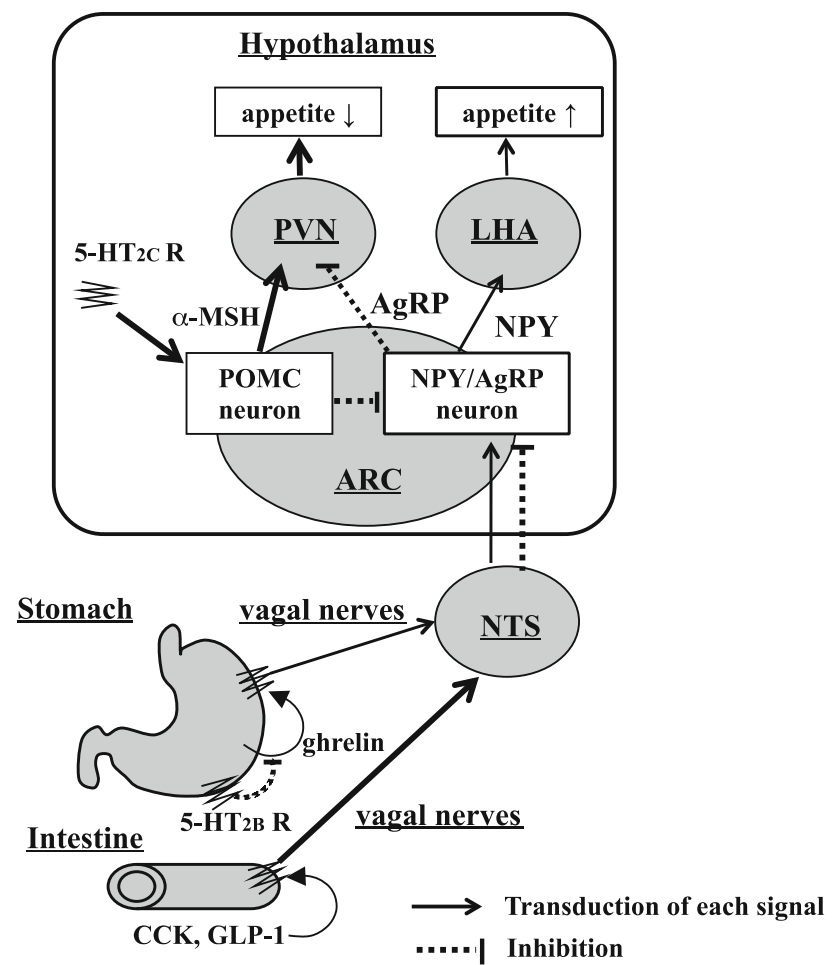

Fig. 6 Appetite signals in the gastrointestinal-brain system. NPY neuropeptide $\mathrm{Y}, A g R P$ agouti-related protein, $M S H$ melanocytestimulating hormone, POMC proopiomelanocortin, NTS nucleus tractus solitaries, $A R C$ arcuate nucleus, $P V N$ paraventricular nucleus, LHA lateral hypothalamic area, CCK cholescystokinin, GLP-1 glucagon-like peptide 1. CCK and GLP-1 secreted from the intestinal I-cells and L-cells stimulate each receptor and the signals are mediated through the afferent vagal nerves and NTS to reduce the expression of NPY and AgRP, and finally reduce the appetite. Stimulation of $5-\mathrm{HT}_{2 \mathrm{~B}}$ receptor in the stomach by 5-HT from chromaffin cells in the intestine inhibits the release of ghrelin which stimulates the appetite through the afferent vagal nerves, and stimulation of the $5 \mathrm{HT}_{2 \mathrm{C}}$ receptor in the hypothalamus stimulates POMC neurons to reduce the appetite

Indian Assam Chaka, the flower buds of $C$. sinensis var. assamica, and their chemical structures were determined. Floraassamsaponins I (17) and II (18) have a sugar moiety at the 28-position, although other acylated oleanane-type triterpene oligoglycosides from Japanese and Chinese Chakas do not have a sugar moiety at this position.

With regard to new biofunctional effects of Indian Assam Chaka, the effect on 42-mer amyloid $\beta$-protein (A $\beta 42)$ aggregation in vitro was examined using the Thioflavin T method. Alzheimer's disease is a neurodegenerative disorder characterized by $\mathrm{A} \beta 42$ aggregation. Previously, various phenolic constituents such as flavonoids and caffeoylquinic acids inhibited A $\beta 42$ aggregation, although studies on this type of saponins have not been attempted [36-38]. The $n$-BuOH-soluble fraction and floraassamsaponins III (19), IV (20), and VII (23) significantly inhibited $\mathrm{A} \beta 42$ aggregation (inhibition 19: $73.4 \pm 8.0 \%, p<0.01 ; \mathbf{2 0}: 68.8 \pm 8.4 \%, p<0.01$; and 23: $56.9 \pm 13.2 \%, p<0.01$ at $100 \mu \mathrm{M}$, respectively). Their effects were almost equivalent to significant suppression of a positive control, morin (inhibition $54.0 \pm 11.2 \%, p<0.01$ at $100 \mu \mathrm{M}$ ), which is known to be one of the most potent natural compounds with inhibitory effects [37]. Further studies (including in vivo investigations) are needed, since this type of compound shows less absorption as described above [28].

In conclusion, we have described the actions of new saponins (classified as acylated oleanane-type triterpene oligoglycosides), which were isolated from Japanese, Anhui, Sichun, and Fujian Chaka and Indian Assam Chaka. Biofunctions beneficial for health promotion, such as antihyperlipidemic, antihyperglycemic, antiobesity, and gastroprotective effects in mice and rats, as well as antiallergic, pancreatic lipase inhibitory, and $A \beta 42$ aggregation inhibitory activities (in vitro) of the extract and newly identified saponin constituents (floratheasaponins, chakasaponin, and floraassamsaponins) were revealed. Furthermore, various bioactive flavonol glycosides and epicatechines, etc. were isolated from each Chaka $[11,12,15,16,18,22]$, apart from their quantitative analyses reported previously $[39,40]$. On the basis of this 
Table 5 Effects of chakasaponins I (11)-III (13) on gastric emptying and gastrointestinal transit in mice. Data were taken and reproduced from references [12] and [16]

\begin{tabular}{llll}
\hline Treatment & $\begin{array}{l}\text { Dose } \\
(\mathrm{mg} / \mathrm{kg}, \mathrm{p} . \mathrm{o} .)\end{array}$ & $\begin{array}{l}\text { Gastric emptying } \\
(\%)\end{array}$ & $\begin{array}{l}\text { Gastrointestinal transit } \\
(\%)\end{array}$ \\
\hline Control & - & $75.0 \pm 4.1$ & $40.0 \pm 2.5$ \\
Chakasaponin I (11) & 25 & $68.5 \pm 5.0$ & $43.8 \pm 1.3$ \\
& 50 & $50.2 \pm 3.0^{* *}$ & $49.1 \pm 4.3$ \\
Control & 100 & $37.9 \pm 1.4^{* *}$ & $81.6 \pm 3.3^{* *}$ \\
Chakasaponin II (12) & - & $73.1 \pm 2.1$ & - \\
& 25 & $65.2 \pm 3.9$ & $64.9 \pm 10.8$ \\
& 50 & $56.9 \pm 2.7^{*}$ & $52.1 \pm 5.8$ \\
Control & 100 & $40.5 \pm 6.7^{* *}$ & $75.6 \pm 11.1^{* *}$ \\
Chakasaponin III (13) & - & $76.8 \pm 2.4$ & - \\
& 25 & $70.7 \pm 1.9$ & $51.0 \pm 3.4$ \\
& 50 & $52.0 \pm 2.7^{* *}$ & $64.2 \pm 6.3^{*}$ \\
Control & 100 & $39.8 \pm 1.7^{* *}$ & $68.5 \pm 2.5^{* *}$ \\
Escin IIa & - & $86.2 \pm 1.3$ & - \\
& 25 & $81.7 \pm 6.5$ & - \\
& 50 & $69.6 \pm 3.0^{*}$ & - \\
\hline
\end{tabular}

Effects on gastric emptying: a solution of $1.5 \%$ carboxymethyl cellulose sodium salt (CMC-Na) containing $0.05 \%$ phenol red as a marker was given $(0.3 \mathrm{~mL} / \mathrm{mouse}$, p.o.) to fasted male ddY mice 30 min before being killed by cervical dislocation under anesthesia. The abdominal cavity was opened, the gastroesophageal junction and pylorus were clamped, and the stomach was removed, weighed, and placed in $10 \mathrm{~mL}$ of $0.1 \mathrm{M} \mathrm{NaOH}$ prior to homogenization, followed by the addition of $5 \mathrm{~mL}$ of the supernatant to $0.5 \mathrm{~mL}$ of $20 \%$ trichloroacetic acid (w/v) for centrifugation. Next, $4 \mathrm{~mL}$ of supernatant was mixed with an equal volume of $0.5 \mathrm{M} \mathrm{NaOH}$, and the amount of phenol red was determined by $560 \mathrm{~nm}$ absorbance. The test sample was given orally $30 \mathrm{~min}$ before the administration of the CMC-Na solution

Gastric emptying $(\%)=(1-$ amount of phenol red in test sample-treated group/amount of administered phenol red) $\times 100$

Effects on gastrointestinal transit: a charcoal meal containing $1.5 \% \mathrm{CMC}-\mathrm{Na}$ solution and $5 \%$ charcoal as a marker was given $(0.2 \mathrm{~mL} /$ mouse, p.o. $)$ to fasted male ddY mice. Fifteen minutes later, the abdominal cavity was opened, and the gastrointestinal tract was removed. The traveled distance of the marker was measured and expressed as a percentage of the total length of the small intestine from the pylorus to the cecum. The test samples were given orally $1 \mathrm{~h}$ before administration of the charcoal meal

Values represent the means $\pm \operatorname{SEM}(n=5-10)$

Significant difference where $* p<0.05$ or $* * p<0.01$ is compared with controls experimental evidence, a variety of health/functional foods and beverages made of Chaka have been developed recently in Japan and Taiwan.

Acknowledgments This work was supported in part by the Academic Frontier Project and a Grant-in-Aid for scientific research from Japan Society for the Promotion of Science [JSPS KAKENHI (Grantin-Aid for Scientific Research (C) 18510194 and 25450144 to $\mathrm{MH}$, 26460135 and 23790028 to NS, 16073221 to YM)] and the Hohansha Foundation, Japan.

\section{References}

1. Yang CS, Zhang J, Zhang L, Huang J, Wang Y (2016) Mechanisms of body weight reduction and metabolic syndrome allevation by tea. Mol Nutr Food Res 60:160-174

2. Kitagawa I, Hori K, Motozawa T, Murakami T, Yoshikawa M (1998) Structures of new acylated oleanene-type triterpene oligoglycosides, theasaponins $\mathrm{E}_{1}$ and $\mathrm{E}_{2}$, from the seeds of tea plant,
Camellia sinensis (L.) O. Kuntze. Chem Pharm Bull 46:1901-1906

3. Murakami T, Nakamura J, Matsuda H, Yoshikawa M (1999) Bioactive saponins and glycosides. XV. Saponin constituents with gastroprotective effect from the seeds of tea plant, Camellia sinensis L. var. assamica Pierre, cultivated in Sri Lanka: structures of assamsaponins A, B, C, D, and E. Chem Pharm Bull 47:1759-1764

4. Murakami T, Nakamura J, Kageura T, Matsuda H, Yoshikawa M (2000) Bioactive saponins and glycosides. XVII. Inhibitory effect on gastric emptying and accelerating effect on gastrointestinal transit of tea saponins: structures of assamsaponins F, G, H, I, and $\mathrm{J}$ from the seeds and leaves of the tea plant. Chem Pharm Bull 48:1720-1725

5. Yoshikawa M, Morikawa T, Li N, Nagatomo A, Li X, Matsuda H (2005) Bioactive saponins and glycosides. XXIII. Triterpene saponins with gastroprotective effect from the seeds of Camellia sinensis - theasaponins $\mathrm{E}_{3}, \mathrm{E}_{4}, \mathrm{E}_{5}, \mathrm{E}_{6}$, and $\mathrm{E}_{7}$. Chem Pharm Bull 53:1559-1564

6. Morikawa T, Li N, Nagatomo A, Matsuda H, Li X, Yoshikawa M (2006) Triterpene saponins with gastroprotective effects from tea seed (the seeds of Camellia sinensis). J Nat Prod 69:185-190 
7. Morikawa T, Matsuda H, Li N, Nakamura S, Li X, Yoshikawa M (2006) Bioactive saponins and glycosides. XXVI. New triterpene saponins, theasaponins $\mathrm{E}_{10}, \mathrm{E}_{11}, \mathrm{E}_{12}, \mathrm{E}_{13}$, and $\mathrm{G}_{2}$, from the seeds of tea plant (Camellia sinensis). Heterocycles 68:1139-1148

8. Yoshikawa M, Morikawa T, Nakamura S, Li N, Li X, Matsuda H (2007) Bioactive saponins and glycosides. XXV. Acylated oleanane-type triterpene saponins from the seeds of tea plant (Camellia sinensis). Chem Pharm Bull 55:57-63

9. Morikawa T, Matsuda H, Li N, Li X, Yoshikawa M (2007) Bioactive saponins and glycosides part 29. Acylated oleananetype triterpene saponins: theasaponins $\mathrm{A}_{6}, \mathrm{~A}_{7}$, and $\mathrm{B}_{5}$ from the seeds of Camellia sinensis. Helv Chim Acta 90:2342-2348

10. Morikawa T, Nakamura S, Kato Y, Muraoka O, Matsuda H, Yoshikawa M (2007) Bioactive saponins and glycosides. XXVIII. New triterpene saponins, foliatheasaponins I, II, III, IV, and V, from Tencha (the leaves of Camellia sinensis). Chem Pharm Bull 55:293-298

11. Yoshikawa M, Morikawa T, Yamamoto K, Kato Y, Nagatomo A, Matsuda H (2005) Floratheasaponins A-C, acylated oleananetype triterpene oligoglycosides with anti-hyperlipidemic activities from flowers of tea plant (Camellia sinensis). J Nat Prod 68:1360-1365

12. Matsuda H, Hamao M, Nakamura S, Kon'i H, Murata M, Yoshikawa M (2012) Medicinal flowers. XXXIII. Anti-hyperlipidemic and anti-hyperglycemic effects of chakasaponins I-III and structure of chakasaponin IV from flower buds of Chinese tea plant (Camellia sinensis). Chem Pharm Bull 60:674-680

13. Yoshikawa M, Wang T, Sugimoto S, Nakamura S, Nagatomo A, Matsuda H, Harima S (2008) Functional saponins in tea flower (flower buds of Camellia sinensis): gastroprotective and hypoglycemic effects of floratheasaponins and qualitative and quantitative analysis using HPLC. Yakugaku Zasshi 128:141-151

14. Hamao M, Matsuda H, Nakamura S, Nakashima S, Semura S, Maekubo S, Wakasugi S, Yoshikawa M (2011) Anti-obesity effects of the methanolic extract and chakasaponins from the flower buds of Camellia sinensis in mice. Bioorg Med Chem 19:6033-6041

15. Yoshikawa M, Nakamura S, Kato Y, Matsuhira K, Matsuda $H$ (2007) Medicinal flowers. XIV. New acylated oleanane-type triterpene oligoglycosides with antiallergic activity from flower buds of Chinese tea plant (Camellia sinensis). Chem Pharm Bull 55:598-605

16. Yoshikawa M, Sugimoto S, Kato Y, Nakamura S, Wang T, Yamashita C, Matsuda H (2009) Acylated oleanane-type triterpene saponins with acceleration of gastrointestinal transit and inhibitory effect on pancreatic lipase from flower buds of Chinese tea plant (Camellia sinensis). Chem Biodiv 6:903-915

17. Ohta T, Nakamura S, Nakashima S, Matsumoto T, Ogawa K, Fujimoto K, Fukaya M, Yoshikawa M, Matsuda H (2015) Acylated oleanane-type triterpene oligoglycosides from the flower buds of Camellia sinensis var. assamica. Tetrahedron 71:846-851

18. Sugimoto S, Yoshikawa M, Nakamura S, Matsuda H (2009) Medicinal flowers. XXV. Structures of floratheasaponin $\mathrm{J}$ and chakanoside II from Japanese tea flower, flowerbuds of Camellia sinensis. Heterocycles 78:1023-1029

19. Morikawa T, Miyake S, Miki Y, Ninomiya K, Yoshikawa M, Muraoka O (2012) Quantitative analysis of acylated oleananetype triterpene saponins, chakasaponins I-III and floratheasaponins A-F, in the flower buds of Camellia sinensis from different regional origins. J Nat Med 66:608-613

20. Matsuda H, Nakamura S, Yoshikawa M (2016) Degranulation inhibitors from medicinal plants in antigen-stimulated rat basophilic leukemia (RBL-2H3) cells. Chem Pharm Bull 6:96-103

21. Park EK, Choo MK, Kim EJ, Han MJ, Kim DH (2003) Antiallergic activity of ginsenoside $\mathrm{Rh}_{2}$. Chem Pharm Bull 26:1581-1584
22. Yoshikawa M, Sugimoto S, Nakamura S, Matsuda H (2008) Medicinal flowers. XXII. Structures of chakasaponins V and VI, chakanoside I, and chakaflavonoside A from flower buds of Chinese tea plant (Camellia sinensis). Chem Pharm Bull 56:1297-1303

23. Hays T, Rusyn I, Burns AM, Kennett MJ, Ward JM, Gonzalez FJ, Peters JM (2005) Role of peroxisome proliferator-activated receptor- $\alpha(\mathrm{PPAR} \alpha)$ in bezafibrate-induced hepatocarcinogenesis and cholestasis. Carcinogenesis 26:219-227

24. Shimpson KA, Martin NM, Bloom SR (2009) Hypothalamic regulation of food intake and clinical therapeutic applications. Arq Bras Endocrinol Metab 53:120-128

25. Takeda H, Sadakane C, Hattori T, Katsurada T, Ohkawara T, Nagai K, Asaka M (2008) Rikkunshito, an herbal medicine, suppresses cisplatin-induced anorexia in rats via $5-\mathrm{HT}_{2}$ receptor antagonism. Gastroenterology 134:2004-2013

26. Yakabi K, Kurosawa S, Tamai M, Yuzurihara M, Nahata M, Ohno S, Ro S, Kato S, Aoyama T, Sakurada T, Takabayashi H, Hattori $\mathrm{T}$ (2010) Rikkunshito and $5-\mathrm{HT}_{2 \mathrm{C}}$ receptor antagonist improve cisplatin-induced anorexia via hypothalamic ghrelin interaction. Regul Pept 161:97-105

27. Hattori T (2010) Rikkunshito and ghrelin. Int J Pept 2010: Article ID 283549, 3 pages

28. Henschler D, Hempel K, Schultze B, Maurer W (1971) The pharmakokinetics of escin. Arzneiimittelforschung 21:1682-1692

29. Côté CD, Zadeh-Tahmasebi M, Rasmussen BA, Duca FA, Lam TK (2014) Hormonal signaling in the gut. J Biol Chem 289:11642-11649

30. Hu JN, Zhu XM, Han LK, Saito M, Sun YS, Yoshikawa M, Kimura Y, Zheng YN (2008) Anti-obesity effects of escins extracted from the seeds of Aesculus turbinata BLUME (Hippocastanaceae). Chem Pharm Bull 56:12-16

31. Matsuda H, Li Y, Murakami T, Yamahara J, Yoshikawa M (1999) Effects of escins Ia, Ib, IIa, and IIb from horse chestnuts on gastric emptying in mice. Eur J Pharmacol 368:237-243

32. Matsuda H, Li Y, Yoshikawa M (2000) Possible involvement of dopamine and dopamine2 receptors in the inhibitions of gastric emptying by escin Ib in mice. Life Sci 67:2921-2927

33. Tominaga K, Kido T, Ochi M, Sadakane C, Mase A, Okazaki H, Yamagami H, Tanigawa T, Watanabe K, Watanabe T, Fujiwara Y, Oshitani N, Arakawa T (2011) The traditional Japanese medicine rikkunshito promotes gastric emptying via the antagonistic action of the 5- $\mathrm{HT}_{3}$ receptor pathway in rats. Evid Based Complement Alternat Med 2011: Article ID 248481, 8 pages

34. Bugajski AJ, Gil K, Ziomber A, Zurowski D, Zaraska W, Thor PJ (2007) Effect of long-term vagal stimulation on food intake and body weight during diet induced obesity in rats. J Physiol Pharmacol 58(Suppl. 1):5-12

35. Matsuda H, Li Y, Yoshikawa M (1999) Effects of escins Ia, Ib, IIa, and IIb from horse chestnuts on gastrointestinal transit and ileus in mice. Bioorg Med Chem 7:1737-1741

36. Ono K, Hamaguchi T, Naiki H, Yamada M (2006) Anti-amyloidogenic effects of antioxidants: implications for the prevention and therapeutics of Alzheimer's disease. Biochim Biophys Acta 1762:575-586

37. Porat Y, Abramowitz A, Gazit E (2006) Inhibition of amyloid fibril formation by polyphenols: structural similarity and aromatic interactions as a common inhibition mechanism. Chem Biol Drug Des 67:27-37

38. Miyamae Y, Kurisu M, Murakami K, Han J, Isoda H, Irie K, Shigemori H (2012) Protective effects of caffeoylquinic acids on the aggregation and neurotoxicity of the 42-residue amyloid $\beta$ protein. Bioorg Med Chem 20:5844-5849

39. Morikawa T, Ninomiya K, Miyake S, Miki Y, Okamoto M, Yoshikawa M, Muraoka O (2013) Flavonol glycosides with lipid accumulation inhibitory activity and simultaneous quantitative analysis of 15 polyphenols and caffeine in the flower buds of 
Camellia sinensis from different regions by LCMS. Food Chem 140:353-360

40. Morikawa T, Lee IJ, Okugawa S, Miyake S, Miki Y, Ninomiya K, Kitagawa N, Yoshikawa M, Muraoka O (2013) Quantitative analysis of catechin, flavonoid, and saponin constituents in "tea flower", the flower buds of Camellia sinensis, from different regions in Taiwan. Nat Prod Commun 8:1553-1557 